\title{
Documented record of the Light-mantled Albatross Phoebetria palpebrata (Foster, 1785) from southeastern Brazil
}

\author{
G. V. V. Corrêa $a^{a}$ and G. A. Pereira ${ }^{b *}$

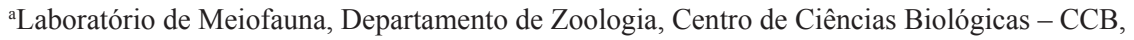 \\ Universidade Federal de Pernambuco - UFPE, Av. Prof. Moraes Rego, 1235, CEP 50670-901, Recife, PE, Brazil \\ 'Laboratório de Ornitologia, Programa de Pós-graduação em Etnobiologia e Conservação da Natureza, \\ Departamento de Biologia, Universidade Federal Rural de Pernambuco - UFRPE, \\ Rua Dom Manuel de Medeiros, s/n, CEP 52171-900, Recife, PE, Brazil \\ *e-mail: glaucoapereira@yahoo.com.br
}

Received: August 14, 2015 - Accepted: October 19, 2015 - Distributed: August 31, 2016

(With 1 figure)

Albatrosses (Procellariiformes: Diomedeidae) are large birds that mostly occur in the Southern Hemisphere (Sick, 1997). This family is represented by ten species in Brazil, two belonging to the genus Phoebetria: the Light-mantled Albatross P. Palpebrata (Foster, 1785) and the Sooty Albatross P. fusca (Hilsenberg, 1822) (CBRO, 2014).

The Light-mantled Albatross has a circumpolar distribution in the Southern Ocean, mostly south of the Subantarctic Convergence between $40^{\circ}$ and $60^{\circ} \mathrm{S}$ (Carboneras, 1992; Brooke, 2004). It is the most abundant albatross in Antarctic waters (Ainley et al., 1984), with strongly pelagic habits (Carboneras, 1992). In Brazil there are very few records of this species, concentrated in the south of the country (Roos and Piacentini, 2003); there is also a record in São Paulo, corrected afterward to Sooty Albatross, and one still unresolved from Bahia (see Roos and Piacentini, 2003). The CBRO (2014) consider the species as a seasonal south visitor, with presumed status, but not yet confirmed.

An adult Light-mantled Albatross was found in 29 April 2014 at 08:45 min, at Vilatur beach (22 56' S; $42^{\circ} 26^{\prime}$ O), municipality of Saquarema, Rio de Janeiro. Its plumage was sooty, with light gray back, vinaceous dark brown head, and darker wings and tail (Figures 1a and b). The bird was identified through the plates and photos of seabird guides and books, the contrasting light gray back, sharply contrasting the white crescent framing the upper half of the eye and the black bill with narrow pale bluish sulcus (central line along ramicorn) clinching the identification (Harrison, 1983, 1987; Enticott and Tipling, 1997; Onley and Scofield, 2007).
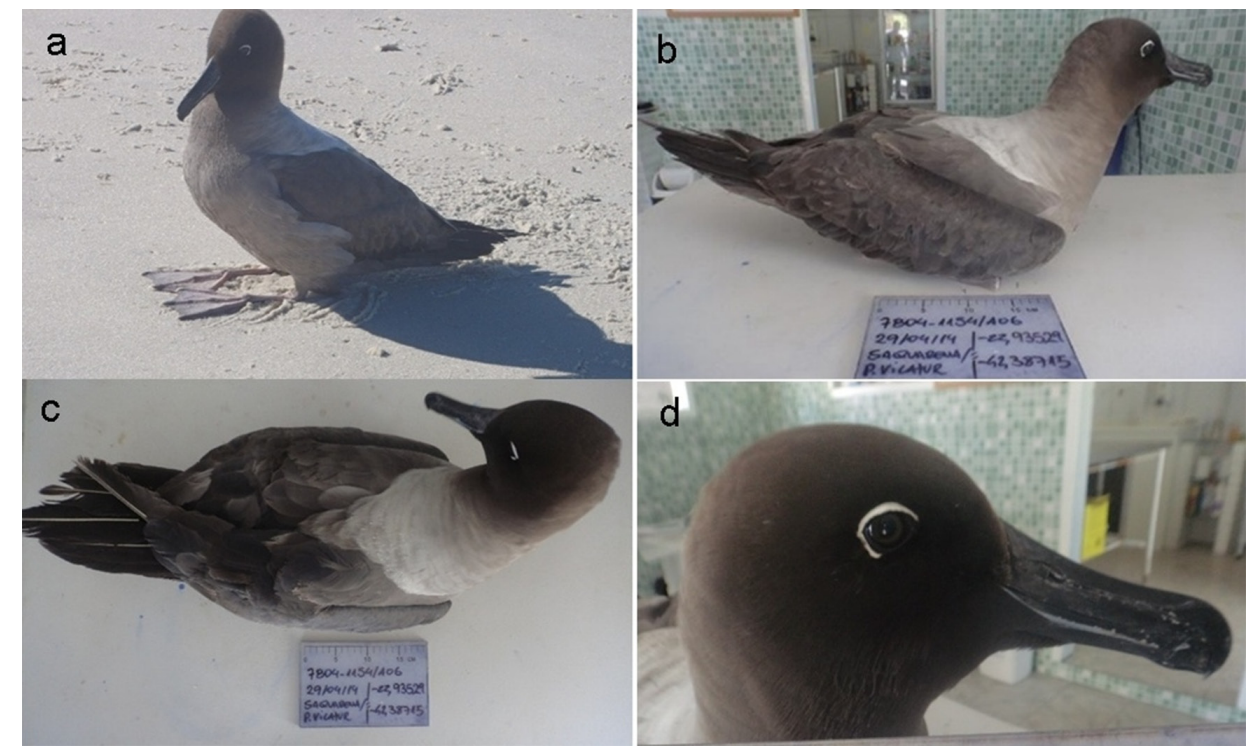

Figure 1. (a) Individual of Light-mantled Albatross found at Vilatur beach, municipality of Saquarema, Rio de Janeiro; (b) side view; (c) Dorsal view showing features of the plumage and the white shafts of the tail; (d) head showing the black bill with bluish sulcus (Photo by Gustavo Corrêa). 
The features of the Light-mantled Albatross are very different from the adult of the Sooty Albatross, although it can be confused with the plumage in the first year of this species (see Harrison, 1983). However the immature Sooty Albatross has a clearer pale head, gray or black sulcus and the tail lacks pale shafts, while the adult of the Light-mantled Albatross has bluish sulcus and white shafts (Figures 1c and d) (Harrison, 1983; Onley and Scofield, 2007). The bird found was quite weak, possibly dehydrated, and unable to take flight. It later died, and there was no time to transport it to some environmental agency or research institution; so, the bird was buried.

This paper is one of the few documented records of Light-mantled Albatross in Brazil, noting that more records should be published in scientific journals to understand more the distribution and dispersion pattern of this species.

\section{Acknowledgements}

We thank to John Medcraft for revising the English and for some comments.

\section{References}

AINLEY, D.G., O'CONNOR, E.F. and BOEKELHEIDE, J.R., 1984. The marine ecology of the Ross Sea, Antarctica. Ornithological Monographs, no. 32, pp. 1-97.
BROOKE, M., 2004. Albatrosses and petrels across the world. New York: Oxford University Press. 240 p.

CARBONERAS, C., 1992. Family Diomedeidae (Albatrosses). In: J. DEL HOYO, A. ELLIOTT and J. SARGATAL, eds. Handbook of the birds of the world: ostrich to ducks. Barcelona: Lynx Edicions, pp. 198-215.

COMITÊ BRASILEIRO DE REGISTROS ORNITOLÓGICOS CBRO, 2014 [viewed 4 February 2015]. Listas das aves do Brasil [online]. Available from: http://www.cbro.org.br

ENTICOTT, J. and TIPLING, D., 1997. Seabirds of the world: the complete reference. New Holland: Stackple Books. 234 p.

HARRISON, P., 1983. Seabirds: an identification guide. Boston: Houghton Mifflin. 448 p.

HARRISON, P., 1987. Seabirds: a photographic guide. London: Christopher Helm. 317 p.

ONLEY, D. and SCOFIELD, P., 2007. Albatrosses, petrels and shearwaters of the World. Princenton: Princenton University Press. 240 p.

ROOS, A.L. and PIACENTINI, V.Q., 2003. Revisão dos registros sul-brasileiros do gênero Phoebetria Reichenbach, 1853 e primeiro registro documentado de Phoebetria palpebrata para Santa Catarina. Ararajuba, vol. 11, no. 2, pp. 223-225.

SICK, H., 1997. Ornitologia brasileira. Rio de Janeiro: Nova Fronteira. 912 p. 